$\mathbf{R}_{\text {ESEARCH }} \mathbf{P}_{\text {APER }} \longrightarrow \frac{\text { FOOD SCIENCE }}{\text { RESEARCH JOURNAL }}$

e ISSN-2230-9403 - Visit us : www. researchjournal.co.in Volume 8 | Issue 2 | October, 2017 | 303-309

DOI : 10.15740/HAS/FSRJ/8.2/303-309

\title{
Processing of roselle (Hibiscus sabdariffa) calyces for value addition
}

\author{
S.V. Ghodke And K.A. Mane
}

Roselle (Hibiscus sabdariffa) belongs to the family Malvaceae. The different part of roselle are the seeds, leave and calyces and these have been used for different uses. Roselle or Hibiscus sabdariffa plant is also reported to be antiseptic, aphrodisiac, astringent, demulcent, digestive, purgative and resolvent. It is used as a folk remedy in the treatment of abscesses, bilious conditions, cancer, cough, debility, dyspepsia, fever, hangover, heart ailments, hypertension, neurosis, scurvy and strangury. The fresh calyces consist of saponins, tannins, cyanogenic glycoside and other phytocochemical such as protocatechuric acid. It also contains antioxidants including flavonoids, gossypetine, hibiscetine and sadderetine. Some of the anthocyanins of roselle identified by chromatographic process include delphinidin -3- sambubioside, cyaniding -3- sambubioside and delphinidin -3-glucose. The aqueous extract and the colouring matter of the calyces are lethal to Mycobacterium tuberculosis. Fresh calyces are rich in pectin and citric acid. Aonla is known for its nutritional qualities being rich in vitamin $\mathrm{C}$ and tannins. Guava is a seasonal fruit and is high in pectin and vitamin A.So present investigationis undertaken to prepare jam using fresh roselle (Hibiscus sabdariffa) calyces, aonla and guava.Three samples of jam are prepared. One is prepared by using only roselle pulp. Other two are prepared by replacingroselle pulp withaonla and guava each at 50\%. Overall acceptability of these sample ranges from 7.2 to 7.55.

Key Words : Roselle, Hibiscus sabdariffa, Jam, Aonla, Guava

How to cite this article : Ghodke, S.V. and Mane, K.A. (2017). Processing of roselle (Hibiscus sabdariffa) calyces for value addition. Food Sci. Res. J., 8(2): 303-309, DOI : 10.15740/HAS/FSRJ/8.2/303-309.

Associate Authors' :

K.A. MANE, MIT College of Food Technology, Rajbag Educational Complex, Loni Kalbhor, Taluka Haveli, PUNE (M.S.) INDIA

Email : kavita83.more@ rediffmail.com 